www.jmscr.igmpublication.org

Impact Factor (SJIF): 6.379

Index Copernicus Value: 79.54

ISSN (e)-2347-176x ISSN (p) 2455-0450

crossrefDOI: https://dx.doi.org/10.18535/jmscr/v6i10.12

Journal Of Medical Science And Clinical Research

IGM Publication

An Official Publication of IGM Publication

\title{
Histopathological Study of Medicolegal Autopsy Specimens
}

\author{
Authors \\ S A K Adil ${ }^{1}$, Nataraju $\mathbf{G}^{2}$, Anjali $\mathbf{P ~ V}^{3^{*}}$ \\ ${ }^{1}$ Assistant Professor, ${ }^{2}$ Professor, ${ }^{3 *}$ Postgraduate, Department of Pathology, MMC \& RI, Mysore, India \\ Corresponding Author \\ Anjali P V \\ Email: puthanveetilanjali@gmail.com
}

\begin{abstract}
Background: Autopsy is an important tool in medicolegal cases to identify the cause and manner of death. Medicolegal cases such as sudden death, road traffic accident and assault involve organs which are prone to infections, inflammations, occupational and neoplastic diseases. Hence, these organs may show incidental findings. Histopathological examination is essential for evaluation of specimens and to correlate the cause of death. This study is done to analyze the incidental histopathological lesions in medicolegal autopssy specimens.

Method: In our study, conducted over a period of 6 months, histopathological examination of 50 medicolegal cases was done. Age and sex distribution, causes of death, organs received and histopathological findings were evaluated.

Results: Out of the 50 cases studied, majority of the patients were in 21-30 years age group. There were 34 males and 16 females. Most frequent cause of death mentioned was sudden death (30\%). Most frequent organs received in study was Heart (29.2\%) followed by Lung (13.3\%) and Skin (12.3\%). Atherosclerosis and Fatty liver were present in 18 and 3 cases respectively.

Conclusion: Histopathological examination can be considered as a useful modality in medicolegal autopsy cases. The most common organs received were Heart and Lungs. The most common incidental findings noted were Atherosclerosis and Fatty Liver.

Keywords: Histopathology, Medicolegal autopsy, Atherosclerosis.
\end{abstract}

\section{Introduction}

Autopsy is an important tool in medicolegal cases to identify the cause and manner of death. ${ }^{1}$ Medicolegal cases such as sudden death, road traffic accident and assault involve organs which are prone to infections, inflammations, occupational and neoplastic diseases. ${ }^{2,3}$ Hence, these organs may show incidental findings. ${ }^{4}$ Histopathological examination is essential for evaluation of specimens and to correlate the cause of death. ${ }^{5}$ This study is done to analyze the incidental histopathological lesions in Medicolegal Autopsy specimens.

\section{Inclusion criteria}

Subjects were selected from Medicolegal

Autopsies irrespective of cause of death.

\section{Exclusion criteria}

Autolysed specimens were excluded. 


\section{Aims and objectives}

1. To study the Histopathological findings of specimens in Medicolegal Autopsy cases.

2. To study age and sex distribution of Medicolegal Autopsy cases.

\section{Methods}

The study was conducted in Histopathology section of Department of Pathology, MMC \& RI, Mysore. This is a prospective study conducted on 50 Postmortem Autopsy cases received during 6 months from January 2018 to June 2018. Gross examination of specimen including measurement, weight, consistency, cut section and details of any lesion if present were recorded. The bits were taken from representative areas of the specimen and were processed for Histopathology. H \& E staining was done.

\section{Result}

Out of the 50 cases studied, majority of the patients were in 21-30 years age group.(Table 1). There were total of 34 males and 16 females (Table 2). Most frequent cause of death mentioned was Sudden death $(30 \%)$ followed by Myocardial Infarction (20\%). Other causes of death mentioned include Electrocution (10\%), Road Traffic Accident (10\%), Gunshot injury (10\%), Assault (6\%), Hanging(6\%), Snake bite $(6 \%)$ and Self fall(2\%). (Table 3) Most frequent organs received in study were Heart $(29.2 \%)$ followed by Lung (13.3\%) and Skin (12.3\%). Other organs received were Brain (11.3\%), Kidney (10.4\%), Liver(8.4\%), Spleen (7.5\%), Uterus(4.8\%), Neck structures (1.9\%) and piece of Bone $(0.9 \%)$.(Table 4$)$

Most common pathological finding was Atherosclerosis (18 cases) (Fig. 1). Other findings in Heart were Cardiac hypertrophy (2 cases), Myocarditis ( 2 cases) and Right Atrial mass( 1 case). Findings in Lungs included Chronic bronchitis (2 cases), intra-alveolar haemorrhage (1 case), Emphysema (1 case)
(Fig.2) and areas of congestion (6 cases). Fatty change (3 cases) (Fig.3) and areas of congestion ( 2 cases) were seen in Liver. Study of 2 cases of Uterus with history of sudden death showed decidualised stroma with villi. Out of 5 cases of Electrocution 3 cases showed streaming of nuclei. Other findings in Skin tissue from cases of Gunshot injury and Snake bite were distortion of epidermis, areas of congestion and inflammation (5 cases). Study of neck structures from cases of hanging showed areas of haemorrhage and congestion ( 2 cases). (Table 5)

Table 1 : Pattern of age distribution

\begin{tabular}{|l|c|}
\hline Age (Years) & No Of Cases \\
\hline $0-10$ & 2 \\
\hline $11-20$ & 1 \\
\hline $21-30$ & 15 \\
\hline $31-40$ & 10 \\
\hline $41-50$ & 8 \\
\hline $51-60$ & 10 \\
\hline $61-70$ & 4 \\
\hline
\end{tabular}

Table 2: Pattern of sex distribution

\begin{tabular}{|l|c|c|}
\hline \multicolumn{1}{|c|}{ Age } & SEX & \\
\hline & Male & Female \\
\hline $0-10$ & 1 & 1 \\
\hline $11-20$ & 1 & 0 \\
\hline $21-30$ & 11 & 4 \\
\hline $31-40$ & 7 & 3 \\
\hline $41-50$ & 5 & 3 \\
\hline $51-60$ & 7 & 3 \\
\hline $61-70$ & 2 & 2 \\
\hline TOTAL & 34 & 16 \\
\hline
\end{tabular}

Table 3: Case distribution based on cause of death

\begin{tabular}{|l|l|c|}
\hline $\begin{array}{l}\text { SL } \\
\text { NO }\end{array}$ & CAUSE OF DEATH & $\begin{array}{c}\text { NO OF } \\
\text { CASES }\end{array}$ \\
\hline 1. & Sudden death & 15 \\
\hline 2. & Gunshot injury & 5 \\
\hline 3. & Electrocution & 5 \\
\hline 4. & Road traffic accident & 5 \\
\hline 5. & Assault & 3 \\
\hline 6. & Hanging & 3 \\
\hline 7. & Snake bite & 3 \\
\hline 8. & Self-fall & 1 \\
\hline 9. & MI & 10 \\
\hline
\end{tabular}




\section{JMSCR Vol||06||Issue||10||Page 75-79||October}

Table 4: Distribution based on organs received

\begin{tabular}{|c|c|c|c|}
\hline SL NO & Organs Received & NO. & $\%$ \\
\hline 1 & Brain & 12 & 11.3 \\
\hline 2 & Heart & 31 & 29.2 \\
\hline 3 & Spleen & 8 & 7.5 \\
\hline 4 & Lung & 14 & 13.3 \\
\hline 5 & Kidney & 11 & 10.4 \\
\hline 6 & Liver & 9 & 8.4 \\
\hline 7 & Uterus & 5 & 4.8 \\
\hline 8 & Piece Of Bone & 1 & 0.9 \\
\hline 9 & Skin & 13 & 12.3 \\
\hline 10 & Neck Structures & 2 & 1.9 \\
\hline \multicolumn{2}{|l|}{ TOTAL } & 106 & 100 \\
\hline
\end{tabular}

Table 5: Distribution of organs based on histopathologial findings

\begin{tabular}{|c|c|c|c|}
\hline $\begin{array}{l}\text { Sl } \\
\text { No }\end{array}$ & $\begin{array}{l}\text { Specimens } \\
\text { Received }\end{array}$ & Histopathological Findings & $\begin{array}{l}\text { No Of } \\
\text { Cases }\end{array}$ \\
\hline 1. & BRAIN & $\begin{array}{l}\text { Oedema } \\
\text { SAH } \\
\text { Congestion } \\
\end{array}$ & $\begin{array}{l}1 \\
1 \\
5\end{array}$ \\
\hline 2. & HEART & $\begin{array}{l}\text { Atherosclerosis } \\
\text { hypertrophy } \\
\text { Myocarditis } \\
\text { Mass in RA } \\
\text { RV papillary muscle necrosis } \\
\text { Congestion }\end{array}$ & $\begin{array}{l}18 \\
2 \\
2 \\
1 \\
1 \\
1\end{array}$ \\
\hline 3. & SPLEEN & Congestion & 6 \\
\hline 4. & LUNG & $\begin{array}{l}\text { Chronic bronchitis } \\
\text { Intra-alveolar haemorrhage } \\
\text { Emphysematous changes } \\
\text { Interstitial edema with amorphous } \\
\text { eosinophilic material } \\
\text { Congestion }\end{array}$ & $\begin{array}{l}2 \\
1 \\
1 \\
1 \\
6\end{array}$ \\
\hline 5. & KIDNEY & Congestion & 7 \\
\hline 6. & LIVER & $\begin{array}{l}\text { Fatty change } \\
\text { Congestion }\end{array}$ & $\begin{array}{l}3 \\
2 \\
\end{array}$ \\
\hline 7. & UTERUS & $\begin{array}{l}\text { Endometrial decidualized } \\
\text { stroma,with villi } \\
\text { Myometrial hypertrophy }\end{array}$ & $\begin{array}{l}2 \\
1 \\
\end{array}$ \\
\hline 8. & SKIN & $\begin{array}{l}\text { Congestion } \\
\text { Streaming of nuclei } \\
\text { Inflammation in dermis } \\
\text { Distorted architect of epidermis and } \\
\text { dermis }\end{array}$ & $\begin{array}{l}3 \\
3 \\
1 \\
1\end{array}$ \\
\hline 9. & $\begin{array}{l}\text { NECK } \\
\text { STRUCTUR } \\
\text { ES } \\
\end{array}$ & Haemorrhage and congestion & 2 \\
\hline
\end{tabular}

Fig. 1: Sections studied from the left coronary artery shows foamy macrophages within subintimal layer

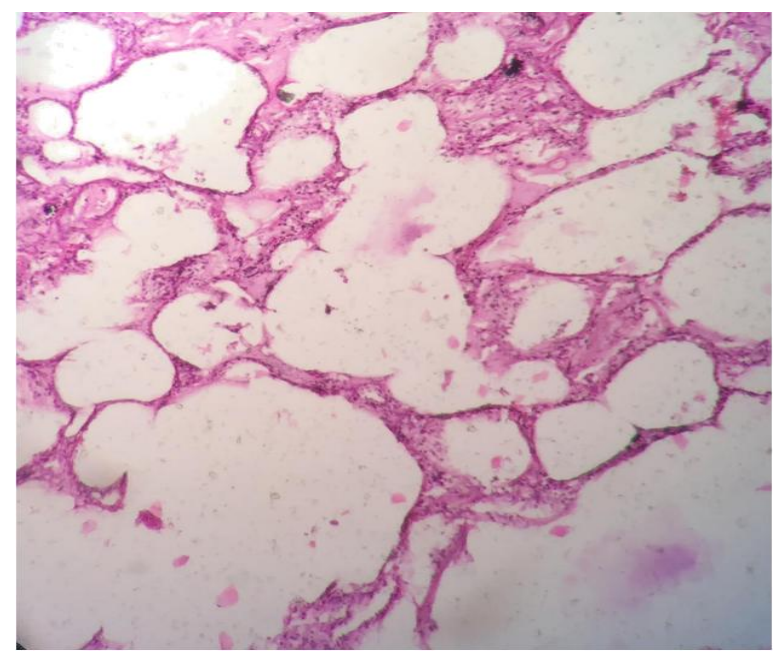

Fig 2: Sections studied from the lungs shows emphysematous changes

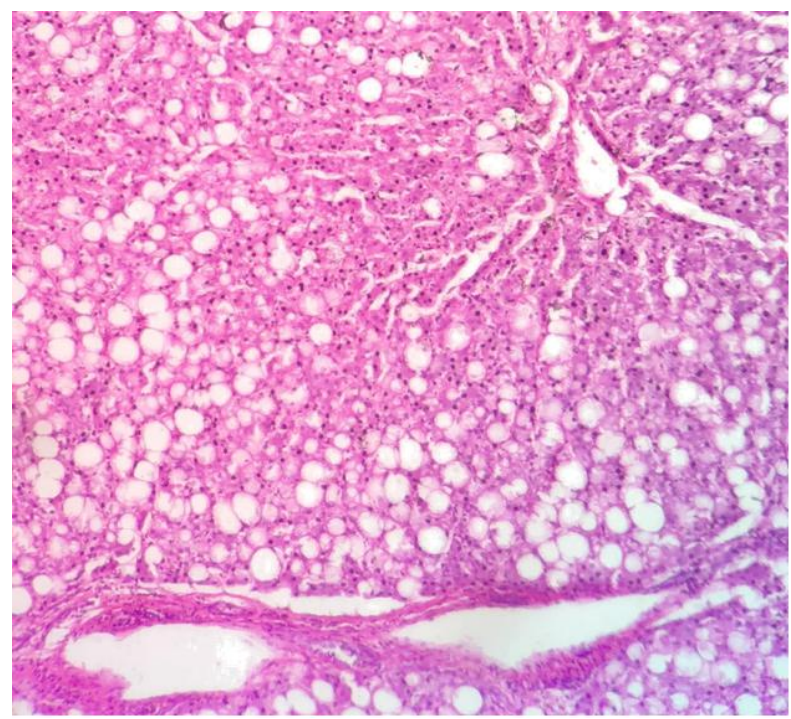

Fig.3 : Sections studied from the liver shows fatty changes 


\section{Discussion}

From this study, it was found that the Histopathological examination of Autopsy specimens has vital role to evaluate cause of death, manner of death and condition of internal visceral organs.

In our study, majority of cases were in 21-30 years age group (30\%) similar to study conducted by Sapna et al $(48.5 \%)$. The main cause of death as reported in patient history were Sudden death (30\%) and Myocardial Infarction $(20 \%)$ whereas study conducted by Tanushi et al showed main causes of death were sepsis with MODS (70\%) and Cardiorespiratory failure (30\%).

In our study Skin, Heart and Lungs were the organs in which Histopathological examination were more efficient as compared to study done by Jani et al were more efficient Histopathological examination were in Uterus, Heart and Brain.

Most common incidental finding was Atherosclerosis (18 cases). This correlated with the study done by P Arunalatha et al (28\%).

\section{Conclusion}

Histopathological examination can be considered as a useful modality in Medicolegal Autopsy cases. Heart, Liver and Lungs were the most commonly received organs among these cases. Histopathological examination of these organs was helpful to identify the cause of death in some of the cases. Most common incidental findings noted were Atherosclerosis followed by Fatty Liver.

\section{References}

1. Nada C K, Muktha R P et al. Role of Histopathology On Autopsy Study: An Audit. SAS Journal of Medicine. 2015; Vol 1; Issue 1:7-15.

2. Smitha S P, Ashok B S et al. Study of Liver Pathology in Autosy cases. International Journal of Current
Research. 2014; Vol 6; Issue 3 : 579597.

3. Puneet G, Aradhna $S$ et al. Spectrum of Pulmonary Histopathological Lesions: A study of 100 Autopsy cases. Journal of Medical Science And Clinical Research. 2017; Vol 5; Issue 12: 31304-08.

4. Arunalatha $\mathrm{P}$, Sangeetha $\mathrm{A}$ et al. Spectrum of Histopathological Findings in Autopsies - Highlighting the Interesting and Incidental Findings. International Journal of Current Medical and Applied Sciences. 2017; 15(2): 6166.

5. Jani C B, Sanjay G et al. Forensic Histopathology: Bane or a Boon?. J Indian Acad Forensic Med; 31(3):22229.

6. Selvam V, Selvi R T et al. Prevalence of common diseases in Lungs and Liver: A Histopathological study. Journal of Pharmaceutical and Biomedical Sciences. 2011; Vol 12; Issue 12: 1-5.

7. Ashok $P$, Harshul $P$ et al. Histopathological Evaluation of Lung Autopsy: 100 cases study. Journal Of Medical Science And Clinical Research. 2018; Vol 6:Issue 3;20-22.

8. Gautam C, Madhuri A. Spectrum of Histopathological lesions in Lung autopsy. Journal of Research in Medical and Dental Science. 2015; Vol 3; Issue 2:100-12.

9. Bhavleen $\mathrm{K}$, Rajiv $\mathrm{K} \mathrm{G}$ et al. Histopathological pattern of lungs on Postmortem Specimen- a study of 100 cases. Annals of International Medical and Dental Research. 2017; Vol 3; Issue 4:1-6.

10. Pratima K, Renu G et al. Prevalence of Lung Lesions at Autopsy: A Histopathological Study. Journal of Clinical and Diagnostic Research. 2017; Vol 11(5):13-16. 
11. Tanushri M, Soma M et al. Retrospective Analysis of Histopathological and Microbiological Correlation of Autopsy series. Journal of Clinical Medicine and Therapeutics. 2017;2:2:1-4.

12. Sapna P, Rajalakshmi B R et al. Histopathological Findings in Autopsies with emphais on Interesting and Incidental Findings- A Pathologists's perspective. Journal of Clinical and Diagnostic Research. 2016; Vol 10(11):8-12.

13. Abedinzadeh N, Behnam $\mathrm{P}$ et al. A Histopathological analyisis of the epidemiology of coronary atherosclerosis: an Autopsy study. Diagnostic Pathology. 2015; 10: 87: 2-8.

14. Rekha N P, Jayashree $\mathrm{T}$ et al. Histopathological examination of skin in electrocution deaths: 1 year autopsy study. Indian Journal of Forensic \& Community Medicine. 2017; 4(4): 25560.

15. Selvambigai G, Amudhavalli $\mathrm{S}$ et al. Histopathological study of lung in autopsy cases: A prospective study. International Journal of Research in Medical Sciences.2016; Vol4 ;Issue 11: 4816-19. 